\title{
Federal fiscal blueprint dodges health concerns
}

Published at www.cmaj.ca on Jan. 28, 2009. Revised on Feb. 10, 2009.

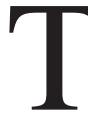

he rhetoric seemed as rushed as the economic plan. Kickstart. Quick fix. Immediate action. Even, enabling quick protective action. Some such form of hasty wording could be found on virtually every page of Finance Minister Jim Flaherty's 2009/10 fiscal blueprint or in virtually every utterance made by federal officials during Jan. 27 background briefings on the new Canadian budget.

Yet, while the minority Conservative government urged all Canadians to hurry out and rebuild the back deck or paint the spare bedroom as part of a 2-year renovation spree in response to the global recession, health-related measures and health infrastructure were all but invisible in Canada's Economic Action Plan, as Flaherty labelled the federal budget.

A \$500-million outlay for the Canada Health Infoway and roughly $\$ 300$ million to promote "greater integration of First Nations health programs with provincial and territorial health systems" were among the few healthrelated initiatives in the blueprint.

Meanwhile, the budgets of the nation's 3 granting councils, including the Canadian Institutes of Health Research, as well as those of Health Canada and the Public Health Agency of Canada, will be slashed over the next 3 years as part of an ongoing exercise aimed at achieving efficiencies in program spending and "realigning" outlays along lines of government priority (see page 498).

But federal officials, who spoke on condition of anonymity during the briefings, argued that the health care system and the medical community aren't facing the same dire circumstances now affecting other sectors of the economy and thus don't require the same sort of stimulus measures.

That includes monies for a national health human resources strategy, said one Finance official. "The fact is that

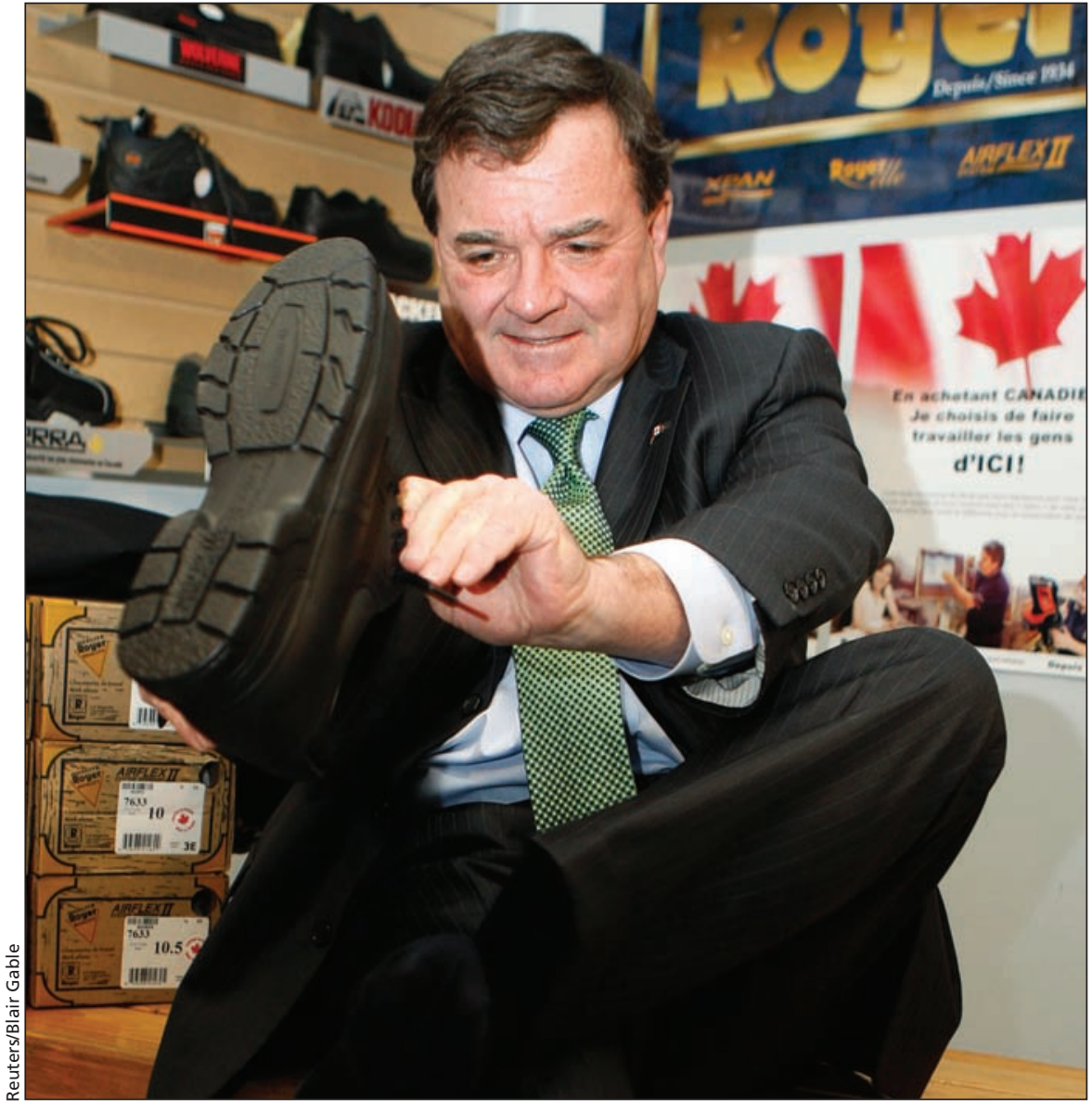

Finance Minister Jim Flaherty tries on his "budget boot" in a Gatineau, Quebec, store. Later, when delivering his budget speech, Flaherty put the boots to research agencies.

the need isn't as great in the health sector right now."

\section{Federal responsibilities}

Moreover, Finance officials and the budget itself sent clear signals that the government does not view health infrastructure and human resource needs as falling within its purview.

Health-sector needs are more than adequately met by the scheduled $6 \%$ increase, to $\$ 24$ billion, in federal payments to the provinces under the Canada Health Transfer "which, de facto, are the federal contribution to health infrastructure and human resources, even though that's not our responsibility," one Finance official argued.
As a consequence, hospitals and other health care facilities are precluded from tapping any of the roughly $\$ 12$ billion in new infrastructure programs that lie at the core of the government's economic stimulus package.

Pamela Fralick, president of the Canadian Healthcare Association and cochair of the Health Action Lobby, a coalition of 36 national health organizations, found it "troubling" that the government so clearly carved out a stance that it is not responsible for health infrastructure or human resources. "We're getting that message loud and clear. And that's very disappointing."

Fralick said a similar measure of disinterestedness appears to apply to 


\section{Risk of research re-exodus raised}

Perhaps the most telling indicator of the place of research in the 2009/10 federal budget, and the almost ad hoc nature of the blueprint, was the fact that days after the release of the economic plan, senior officials at Canada's 3 granting councils were still reeling in confusion.

The council budgets had taken a body blow, as Finance Minister Jim Flaherty's blueprint announced that the Canadian Institutes of Health Research (CIHR), the Natural Sciences and Engineering Research Council and the Social Sciences and Humanities Research Council would have $\$ 17.7$ million trimmed from their base budget allocations this year, \$43 million cut in fiscal 2010/11 and \$87.2 million cut in 2011/12, as their contribution to the ongoing "Strategic Review" exercise that is aimed at realigning spending along lines of Conservative government priority.

Finance officials said during the background budget briefings that the cuts were aggregated, so the net effect will be a $\$ 147.9$-million reduction in granting council budgets over 3 years. The officials said each council would provide details regarding the blow it must absorb.

But the councils say they haven't yet been informed of such details. It's even unclear, in their minds, whether the end result is an \$87.7-million (with the third year total including previous year reductions) or a $\$ 147.9$-million blow.

"Who knows?" says one senior council official, who spoke on condition of anonymity, as the agencies were ordered by the Prime Minister's Office to refuse media interviews on budgetary matters. "It's not at all clear what's going on. One minister tells us it's cumulative. Another says it isn't. I'm not even sure that the government knows."

Even the share of the cuts that each council would have to absorb is unclear, although the expectation is that their budgets will be reduced by the same percentage. Currently, CIHR's base budget is $\$ 733.3$ million. The Natural Sciences and Engineering Research Council's budget is $\$ 709$ million, while that of the Social Sciences and Humanities Research Council is $\$ 249$ million.

The councils expected that some clarity would be achieved at a scheduled meeting in mid-February, after $C M A J$ went to print. The councils also indicated that any decisions on specific program cuts they have to make as a result of the base budget reductions cannot be made until they know exactly what they're dealing with.

The lack of clarity and the budget's failure to bolster support for research grants left the scientific community fearing the ultimate outcome will be a reverse exodus of researchers to the United States, particularly after newly elected President Barack Obama recently unveiled an American economic stimulus package that funnels billions of dollars into science and research infrastructure.

Association of Universities and Colleges of Canada President Claire Morris and Canadian Association of University Teachers Executive-Director Jim Turk argued that researchers will inevitably look south for greener (read \$) research pastures, as the council cuts will compress already declining success rates in grant competitions.

Ultimately, such cuts work to offset gains made over the past decade as a result of faculty recruitment programs such as Canada Research Chairs, they said.

There's a risk there will be a "flow" of researchers back to the United States "if we don't have the environment that produces the top-class facilities, the top-class people, and the money to do the research. That's kind of the question mark, whether there's a little imbalance there," says Morris.

Turk says the so-called brain gain of the past decade could easily become a brain redrain. "For a lot of scientists, I think the attraction of the United States will be compelling."

While direct research funding took a hit, Flaherty's fiscal blueprint was not entirely devoid of research-related measures, which included:

- Universities and colleges will receive $\$ 2$ billion over 2 years to "repair, retrofit and expand facilities." The monies will be available from Industry Canada and the program is intended "for fixing roofs, deferred maintenance, that kind of thing, not for new equipment," a Finance official said. The money will be split 70:30 between universities and colleges. There will be some form of matching dollar requirement for the postsecondary institutions. In a marked departure from traditional scientific peer review, decisions on which specific projects will be supported will be made by Industry Canada.

- The Canada Foundation for Innovation received \$150 million to top up its current "Leading Edge and New Initiatives Funds Competition," while \$600 million has been set aside for a new research infrastructure competition to be established by 2011 , on the provisos that the monies are spent in areas deemed a "priority" by the federal industry minister and that the foundation develops a new strategic plan.

- \$2 million was set aside to conduct a "feasibility study" for a proposed Arctic research station (CMAJ 2009;180[1]:29). An additional \$85 million over 2 years was funnelled into "maintaining or upgrading key existing Arctic research facilities."

- $\$ 87.5$ million will be spent over 3 years to "temporarily expand" the Canada Graduate Scholarships program, of which $\$ 35$ million will issue to CIHR. The expansion will create an additional 500 doctoral scholarships, valued at $\$ 35000$ per year for 3 years, beginning in 2009/10, as well as an additional 1000 master's scholarships, valued at $\$ 17500$ for 1 year, in each of 2009/10 and 2010/11. Scholarships at the Social Sciences and Humanities Research Council will be "focused on business-related degrees."

- An additional \$50-million outlay will issue to develop the Institute for Quantum Computing in Waterloo, Ontario. 
outlays for public health. She noted that while the government has repeatedly indicated over the past year that it would bolster funding for public health programming in areas such as food safety and drug oversight, the budget contains nothing to that effect. The budget does, however, contain a program that sets aside $\$ 250$ million over 2 years to modernize food inspection labs and other federal facilities. But it suggests that priority will be given to the upgrade of labs "for which a realistic business plan is submitted for the transfer of the facility to a university, business or non-profit organization."

Canadian Medical Association President Dr. Robert Ouellet lamented the absence of monies aimed at redressing the national shortage of physicians and other health professionals. "All the political parties, during the election campaign, promised something on that," he notes. But he welcomed additional funding for electronic record keeping.

\section{Health infrastructure}

Without question, the \$500-million outlay for the Canada Health Infoway is the single measure that could have the greatest impact on physicians and the health community. The previous $\$ 1.6$ billion that the independent, nonprofit corporation had received was primarily aimed at large electronic systems such as drug and lab information networks within hospitals. But Finance officials said at least half of the new monies are intended for projects aimed at getting individual physicians to start keeping electronic health records for their patients.

"The goal is to have $50 \%$ of all Canadians with electronic health records by the end of 2010," said one official. Although program details are sparse and must still be ironed out with the provinces, it is expected physicians will eventually receive some measure of direct financial aid to purchase electronic equipment or hire staff that would be necessary as part of any move toward electronic record keeping.

In a related measure, the budget introduced a temporary $100 \%$ Capital Cost Allowance Rate for computer hardware and systems software acquired before Feb. 1, 2011, for which physicians would be eligible. The move is projected to cost the government $\$ 340$ million in the coming fiscal year and $\$ 355$ million in 2010/11.

\section{First Nations health}

Federal officials also touted a $\$ 305$ million, 2-year outlay to improve health outcomes for First Nations peoples as an indication that the health sector was not ignored in the budget.

The new monies are part of a broad, ongoing initiative that aims to have the provinces, rather than the federal government, provide health services for First Nations peoples living on reserves, including expanded availability of noninsured services such as dental care, eye care and prescription drugs.

Finance officials said no province has yet made a commitment to provide such services. But they argued that's primarily because negotiations haven't been completed on how such a shift in health care delivery will be financed. They also claimed that the provinces have expressed reluctance to become involved until existing health facilities on reserves are upgraded. To that end, the budget provides $\$ 135$ million over 2 years to renovate health clinics and nurses' residences on reserves.

\section{Other health measures}

Overall, federal spending will rise by $\$ 21.2$ billion in $2009 / 10$, to $\$ 258$ billion, while the government will run a deficit of $\$ 33.7$ billion. Within that lay a few other health-related measures, including:

- $\$ 50$ million over 2 years to assist the provinces and territories in developing a "common framework" for assessing the foreign credentials of immigrants, including medical professionals.

- \$165 million over 2 years for completion of drinking water and wastewater infrastructure programs in 18 First Nations communities.

- Atomic Energy of Canada Ltd. received a whopping increase for the second consecutive year. Its budget was topped up by $\$ 351$ million, with federal officials saying a "small portion" of that is aimed at assessing how the lifetime of the aging National Research Reactor might be extended beyond 2011 to ensure some measure of domestic medical isotope supply in

\section{Budget highlights}

Finance Minister Jim Flaherty's 2009/10 fiscal blueprint offered nothing in the way of support for health infrastructure or health human resources. Highlights included:

\section{Transfer payments}

Federal payments to the provinces under the Canada Health Transfer rise $6 \%$ to $\$ 24$ billion.

\section{Health Infoway}

Roughly half of a \$500-million allocation for electronic record keeping is expected to be issued to physicians to purchase equipment and hire staff.

\section{Provincial delivery}

The government will spend $\$ 305$ million over 2 years to persuade the provinces to deliver health services to First Nations people living on reserves.

the wake of its recent shutdown and the cancellation of its replacement, the flawed Multipurpose Applied Physics Lattice Experiment reactors (CMAJ 2008;178[5]:536-8, CMAJ 2008;178 [6]:668 and CMAJ 2008;178[13]: 1648).

- The budgets for Health Canada and the Public Health Agency of Canada will be reduced by an aggregate $\$ 167.8$ million over the next 3 years. No details were provided.

The projected \$33.7-billion deficit for 2009/10 marks the first time since $1996 / 97$ that the federal government will operate in the red.

The budget received parliamentary approval after the Conservatives reached an agreement for support from the opposition Liberals, conditional on providing 3 fiscal updates over the course of the coming year. The agreement scuttled the erstwhile Liberal-New Democrat coalition which had threatened to sink the minority government last year after the Conservatives unveiled a mini-budget that provided no economic stimulus, while gutting financing for opposition parties. In the ensuing melee, it took an extraordinary measure - proroguing Parliament - for the government to stave off defeat. - Wayne Kondro, CMAJ

DOI:10.1503/cmaj.090166 